Protocol

\title{
RNase Footprinting to Map Sites of RNA-Protein Interactions
}

Timothy W. Nilsen

The binding of a protein to an RNA sequence protects that the region of the RNA from ribonuclease (RNase) digestion; this protected region is known as the protein's "footprint." In this protocol, endlabeled RNAs with and without bound protein are digested with RNase, and the products of digestion are analyzed by gel electrophoresis on denaturing polyacrylamide gels. If the experiment is performed properly, a comparison of the banding patterns from the two samples will reveal the binding site of the protein. The binding site-or footprint—-will be detected as a region without bands in the proteinbound sample. In the sample without bound protein, the bands should cover the entirety of the RNA molecule. To establish appropriate digestion conditions for the procedure (i.e., $\leq 1$ cleavage event per molecule), it is necessary to titrate the amount of RNase under a range of time and temperature conditions. RNase I cleaves after every nucleotide of RNA and works well under many assay conditions, but other enzymes with different cleavage specificities can also be used. RNase VI is preferable when analyzing structured RNA; RNase A is preferable when using pyrimidine-rich RNAs; and RNase T1 is useful for Grich RNAs. Choosing enzymes with preference for double-stranded (such as RNase VI) versus singlestranded (such as RNase I) RNA may be helpful. Often, a combination of nucleases is advantageous.

It is essential that you consult the appropriate Material Safety Data Sheets and your institution's Environmental Health and Safety Office for proper handling of equipment and hazardous materials used in this protocol.

RECIPES: Please see the end of this protocol for recipes indicated by $<R>$. Additional recipes can be found online at http://cshprotocols.cshlp.org/site/recipes.

\section{Reagents}

Aurintricarboxylic acid (ATA; $5 \mathrm{mg} / \mathrm{mL}$ in $50 \mathrm{~mm}$ Tris [pH 7.5]; Sigma-Aldrich)

EDTA (0.2 M, pH 8.0)

Ethanol (100\%)

Formamide gel-loading buffer $<\mathrm{R}>$

GlycoBlue $(10 \mathrm{mg} / \mathrm{mL})$

$\mathrm{NaOH}(1 \mathrm{~N})$

Phenol

Polyacrylamide gels (8\%-10\%) and electrophoresis reagents

Protein of interest and suitable binding buffer (see Steps 9 and 15)

RNA sample of interest (end-labeled and purified)

See 5'-End Labeling of RNA with [ $\gamma$ - ${ }^{32}$ P]ATP and T4 Polynucleotide Kinase (Rio 2014b), 3'-End Labeling of RNA with [5'- ${ }^{32}$ P]Cytidine 3',5'-Bis(phosphate) and T4 RNA Ligase 1 (Nilsen 2014b), or 3'-End Labeling of RNA with

Adapted from RNA: A Laboratory Manual by Donald C. Rio, Manuel Ares Jr, Gregory J. Hannon, and Timothy W. Nilsen. CSHL Press, Cold Spring Harbor, NY, USA, 2011.

(C) 2014 Cold Spring Harbor Laboratory Press

Cite this protocol as Cold Spring Harb Protoc; doi:10.1101/pdb.prot080788 
T.W. Nilsen

\section{Equipment}

Denaturing polyacrylamide gel electrophoresis system and power supply

Gel plates must be thoroughly cleaned with a solution of 5\% SDS before use.

Dry ice

Gel dryer

Ice

SpeedVac

Water baths or heat blocks (set at the binding temperature [see Steps 9 and 15], at $30^{\circ} \mathrm{C}$ or $50^{\circ} \mathrm{C}$ [see

Steps 1 and 2], and at $95^{\circ} \mathrm{C}$ )

Whatman 3 MM paper

\section{METHOD}

Preparing Markers

Create sequencing markers from the end-labeled RNA by partial T1 digestion (Step 1) or base hydrolysis (Step 2).

1. Prepare T1 markers as follows.

i. Incubate $100,000 \mathrm{cpm}$ of end-labeled RNA in $10 \mu \mathrm{L}$ of 1 sequencing buffer for $10 \mathrm{~min}$ at $50^{\circ} \mathrm{C}$.

ii. Stop the reaction with $2 \mu \mathrm{L}$ of ATA and $12 \mu \mathrm{L}$ of loading buffer.

2. Generate an alkaline ladder as follows.

i. Deliver $100,000 \mathrm{cpm}$ of end-labeled RNA into $9 \mu \mathrm{L}$ of 2 mм EDTA (pH 8.0) containing $20 \mu \mathrm{g}$ of E. coli tRNA.

ii. Add $1 \mu \mathrm{L}$ of $1 \mathrm{~N} \mathrm{NaOH}$ and incubate for $20 \mathrm{~min}$ at $30^{\circ} \mathrm{C}$.

iii. Stop the reaction by adding $2 \mu \mathrm{L}$ of $1 \mathrm{~m}$ Tris- $\mathrm{HCl}(\mathrm{pH} 8)$ and freeze on dry ice until solid. When required, add an equal volume of loading buffer and thaw to room temperature.

\section{Establishing RNase Digestion Conditions}

It is important to determine the nuclease concentration that yields a pattern of fragments that covers the entirety of the $R N A$ ( $\leq 1$ cleavage event per molecule). Titrations are performed on naked end-labeled RNA.

3. Resuspend an end-labeled RNA ( $5^{\prime}$ or $3^{\prime}$ ) in $\mathrm{H}_{2} \mathrm{O}$ and adjust to $\sim 25,000 \mathrm{cpm} / \mu \mathrm{L}$.

4. Set up a series of series of dilutions of RNase I in $10 \mu \mathrm{L}$ of RNase I dilution buffer.

For example, for the dilution series, use $0,0.3,1.0,3.0$, and 0.9 units of RNase $I$. 
5. To each enzyme dilution, add a mixture of $25,000-50,0000 \mathrm{cpm}$ end-labeled RNA with $10 \mu \mathrm{g}$ of $E$. coli tRNA.

The addition of "carrier" RNA to the digestions helps to keep the reactions reproducible and easier to control.

6. Incubate the reactions for $5 \mathrm{~min}$ at $4^{\circ} \mathrm{C}$ and at room temperature.

7. Stop the reactions by adding an equal volume of denaturing gel-loading buffer.

8. Analyze the extent of cleavage for each reaction by electrophoresis of the samples through an $8 \%$ denaturing polyacrylamide gel.

The optimal concentration will show unreacted substrate and a ladder of bands below it. Overdigestion will yield only small fragments. Choose the amount of enzyme that gives a pattern of bands representing cleavage after each nucleotide with some ( $20 \%$ ) of the transcript remaining uncleaved.

\section{Footprinting with RNase I}

These procedures are illustrated in Figure $1 \mathrm{~A}$.

9. Using the same amount of substrate as in Step 5, set up a series of binding reactions with increasing amounts of protein. Include a no-protein control.

Binding conditions can be established using a filter-binding assay (see Filter-Binding Assay for Analysis of RNA-Protein Interactions [Rio 2012]) or a gel-shift assay (see Electrophoretic Mobility Shift Assays for RNA-Protein Complexes [Rio 2014C]).

10. After binding is complete, add $10 \mu \mathrm{g}$ of tRNA and the amount of RNase I determined in Step 8. Incubate according to the appropriate RNase I conditions used in Step 6.

It may be necessary to try two to three enzyme concentrations (one above and one below the optimum).

A

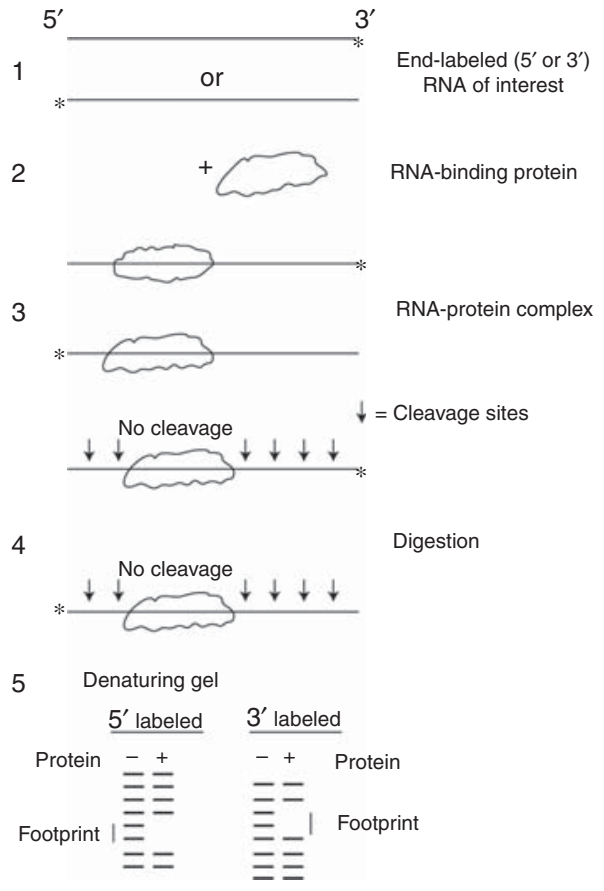

B

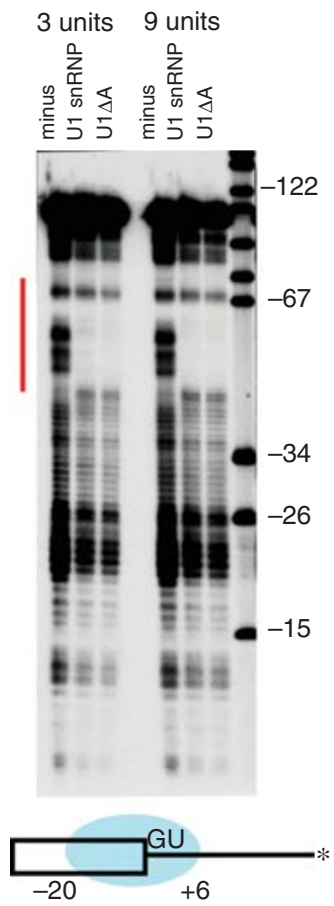

FIGURE 1. (A) A "typical" footprinting experiment. (B) Example of RNase I footprinting. An end-labeled molecule containing a 5' splice site (shown schematically below the gel) was digested with RNase I either in the absence (lanes minus) or presence of $U 1$ snRNP either containing (lanes $U 1$ snRNP) or lacking (lanes $U 1 \Delta A$ ) U1-specific protein U1A. A clear footprint that covers the $5^{\prime}$ splice site region is observed. 
T.W. Nilsen

11. Add $0.2 \mathrm{~mL}$ of SDS extraction buffer to stop the reactions.

RNase I is inactivated by SDS.

12. Recover the RNAs by phenol extraction and ethanol precipitation (adding $20 \mu \mathrm{g}$ of GlycoBlue as carrier). Alternatively, add 2 volumes of gel-loading dye and analyze $\sim 10,000 \mathrm{cpm}$ on a denaturing polyacrylamide gel. Freeze the remainder at $-80^{\circ} \mathrm{C}$.

13. Analyze the footprints by polyacrylamide gel electrophoresis as in Step 8. Load an equal cpm of markers (from Steps 1 or 2) and sample (from Step 12) onto the gel. Carefully pour the bottom buffer out of the gel apparatus to avoid nuclease contamination, and clean the gel plates with a solution of $5 \%$ SDS.

Sample results are shown in Figure 1B. See Troubleshooting.

\section{Footprinting with Other Nucleases}

14. Titrate the selected enzyme(s) as described in Steps 3-8 until suitable cleavage patterns are observed on denaturing polyacrylamide gels.

Look for a uniform ladder with a "core" of undigested RNA at the top. Once the optimal times and enzyme concentrations are found, they should remain consistent and reproducible.

15. Set up a series of binding reactions as in Step 9.

Because RNase VI requires magnesium for cleavage, it must be included in the protein binding buffer.

16. Add $10 \mu \mathrm{g}$ of carrier tRNA to each sample, and then add the amount of enzyme determined in Step 14. Incubate the reactions under the conditions determined in Step 14.

17. Add $3 \mu \mathrm{L}$ of ATA and mix by pipetting up and down.

18. Dilute the reactions with $200 \mu \mathrm{L}$ of SDS extraction buffer and add $0.3 \mathrm{~m}$ sodium acetate. Recover the RNA by phenol extraction and ethanol precipitation (adding $20 \mu \mathrm{g}$ of GlycoBlue as carrier).

If the protein concentration is low and the buffer does not interfere with gels, the samples can be analyzed directly after addition of ATA without purification. Add an equal volume of urea loading dye and load 5- $\mu \mathrm{L}$ samples onto a gel. This is not advisable for samples containing RNase $A$.

19. Resuspend the RNA in $5 \mu \mathrm{L}$ of $\mathrm{H}_{2} \mathrm{O}$ and add $10 \mu \mathrm{L}$ of formamide gel loading buffer. Load $\sim 5-\mu \mathrm{L}$ samples and carry out electrophoresis through a denaturing $8 \%-10 \%$ polyacrylamide gel.

20. Dry the gel and visualize the bands by phosphorimager or autoradiography.

See Troubleshooting.

Problem (Steps 13 and 20): The footprint observed after electrophoresis of the cleaved binding complex is fuzzy or unclear.

Solution: For footprinting to be successful, it is necessary that a substantial fraction $(\geq 80 \%)$ of the target RNA be bound. If less RNA is bound, the unbound RNA, even in the protein-binding site, will be digested, thus obscuring the signal. Consider the following.

- In Steps 9 and 15, make sure that $100 \%$ of the RNA is bound in some reactions.

- Purify the binding complexes from Steps 9 or 15 by binding with antibody or tagged proteins and selecting with an affinity reagent. The nuclease cleavage reactions can be performed while the complex is bound to beads. If cleavage is performed in the presence of beads, it may be necessary to increase the time of digestion. Stop the reactions by adding $0.2 \mathrm{~mL}$ of SDS extraction buffer, remove the beads by centrifuging in a microcentrifuge for $5 \mathrm{sec}$, and continue with RNA recovery by phenol extraction as in Step 12 .

- Reverse footprinting has a distinct advantage over conventional footprinting in that only a small fraction of the labeled RNA needs to be bound. See Reverse Footprinting to Map Sites of RNAProtein Interactions (Nilsen 2014a). 
Formamide Gel-Loading Buffer

\begin{tabular}{lcr} 
Reagent & Quantity (for $10 \mathrm{~mL})$ & Final concentration \\
\hline Deionized formamide & $9.5 \mathrm{~mL}$ & $95 \%$ \\
Bromophenol blue & $2.5 \mathrm{mg}$ & $0.025 \%(\mathrm{w} / \mathrm{v})$ \\
Xylene cyanol FF & $2.5 \mathrm{mg}$ & $0.025 \%(\mathrm{w} / \mathrm{v})$ \\
EDTA $(0.5 \mathrm{M}, \mathrm{pH} 8.0)$ & $100 \mu \mathrm{L}$ & $5 \mathrm{mM}$ \\
$\mathrm{H}_{2} \mathrm{O}$ & $400 \mu \mathrm{L}$ &
\end{tabular}

Store in aliquots at $-20^{\circ} \mathrm{C}$.

RNase I Dilution Buffer

Reagent Quantity (for $10 \mathrm{~mL}$ ) Final concentration

Tris $(1 \mathrm{M}, \mathrm{pH} 8.0)$

$\mathrm{NaCl}(5 \mathrm{M})$

EDTA (0.5 M, pH 8.0)

Glycerol $(50 \%, \mathrm{w} / \mathrm{v})$

Store indefinitely at $4^{\circ} \mathrm{C}$

SDS Extraction Buffer

Reagent

Quantity (for $500 \mathrm{~mL}$ )

$$
\begin{gathered}
0.2 \mathrm{~mL} \\
0.2 \mathrm{~mL} \\
20 \mu \mathrm{L} \\
4 \mathrm{~mL}
\end{gathered}
$$

$20 \mathrm{~mm}$

$100 \mathrm{~mm}$

$1 \mathrm{~mm}$

$20 \%(\mathrm{w} / \mathrm{v})$

Final concentration
$10 \mathrm{~mL}$

$1 \mathrm{~mL}$

$25 \mathrm{~mL}$

$464 \mathrm{~mL}$

EDTA $(0.5 \mathrm{~m}, \mathrm{pH} 8.0)$

SDS $(10 \% \mathrm{w} / \mathrm{v})$

$\mathrm{H}_{2} \mathrm{O}$

Store indefinitely at room temperature.

\section{T1 Sequencing Buffer}

Reagent

Sodium acetate ( $3 \mathrm{~m}, \mathrm{pH} 5.3$ )

Urea (molecular biology grade)

EDTA (0.5 M, pH 8.0)

$\mathrm{H}_{2} \mathrm{O}$

Store for 6 mo at room temperature.

Urea Loading Dye

Reagent

Quantity (for $10 \mathrm{~mL}$ )

Urea

Tris- $\mathrm{HCl}$ (1 M, pH 8.0)

EDTA $(0.25 \mathrm{~m})$

Bromphenol blue/xylene cyanol $(1 \%, w / v)$

$\mathrm{dd}_{2} \mathrm{O}$
Quantity (for $1 \mathrm{~mL}$ )

Final concentration

$6.6 \mu \mathrm{L}$

$0.42 \mathrm{~g}$

$20 \mathrm{~mm}$

$7 \mathrm{M}$

$2 \mu \mathrm{L}$

$1 \mathrm{mM}$

adjust to $1 \mathrm{~mL}$
$20 \mathrm{~mm}$

$1 \mathrm{~mm}$

$0.5 \%(\mathrm{w} / \mathrm{v})$ 
T.W. Nilsen

\section{REFERENCES}

Nilsen TW. 2014a. Reverse footprinting to map sites of RNA-protein interactions. Cold Spring Harb Protoc doi: 10.1101/pdb.prot080804.

Nilsen TW. 2014b. $3^{\prime}$-end labeling of RNA with $\left[5^{\prime}-{ }^{32} \mathrm{P}\right]$ cytidine $3^{\prime}, 5^{\prime}$-bis (phosphate) and T4 RNA ligase 1. Cold Spring Harb Protoc doi: 10.1101/ pdb.prot080713.

Rio DC. 2012. Filter-binding assay for analysis of RNA-protein interactions. Cold Spring Harbor Protoc doi: 10.1101/pdb.prot071449.
Rio DC. 2014a. $3^{\prime}$-end labeling of RNA with yeast poly(A) polymerase and $3^{\prime}$-deoxyadenosine $5^{\prime}-\left[\alpha-{ }^{32} \mathrm{P}\right]$ triphosphate. Cold Spring Harb Protoc doi: $10.1101 /$ pdb.prot 080770 .

Rio DC. 2014b. $5^{\prime}$-end labeling of RNA with $\left[\gamma_{-}{ }^{32} \mathrm{P}\right] \mathrm{ATP}$ and T4 polynucleotide kinase. Cold Spring Harb Protoc doi: 10.1101/pdb.prot080739.

Rio DC. 2014c. Electrophoretic mobility shift assays for RNA-protein complexes. Cold Spring Harb Protoc doi: 10.1101/pdb.prot080721. 


\section{RNase Footprinting to Map Sites of RNA-Protein Interactions}

Timothy W. Nilsen

Cold Spring Harb Protoc; doi: 10.1101/pdb.prot080788

\begin{tabular}{|c|c|}
\hline $\begin{array}{r}\text { Email Alerting } \\
\text { Service }\end{array}$ & Receive free email alerts when new articles cite this article - click here. \\
\hline $\begin{array}{l}\text { Subject } \\
\text { Categories }\end{array}$ & $\begin{array}{l}\text { Browse articles on similar topics from Cold Spring Harbor Protocols. } \\
\text { Characterization of Protein Complexes ( } 83 \text { articles) } \\
\text { Electrophoresis (57 articles) } \\
\text { Electrophoresis of Nucleic Acids ( } 62 \text { articles) } \\
\text { Electrophoresis of RNA ( } 23 \text { articles) } \\
\text { Molecular Biology, general (1293 articles) } \\
\text { RNA (317 articles) } \\
\text { RNA, general (269 articles) }\end{array}$ \\
\hline
\end{tabular}

